\title{
BMJ Global Health Multisector governance for nutrition and early childhood development: overlapping agendas and differing progress in Pakistan
}

\author{
Shehla Zaidi, ${ }^{1}$ Zulfiqar Bhutta, ${ }^{2}$ Syed Shahzad Hussain, ${ }^{3}$ Kumanan Rasanathan ${ }^{4}$
}

To cite: Zaidi S, Bhutta Z, Hussain SS, et al. Multisector governance for nutrition and early childhood development: overlapping agendas and differing progress in Pakistan. BMJ Glob Health 2018;3:e000678. doi:10.1136/ bmjgh-2017-000678

Handling editor Seye Abimbola

Received 13 December 2017

Revised 3 June 2018

Accepted 4 June 2018

\section{Check for updates}

${ }^{1}$ Department of Community Health Sciences and Women and Child Health Division, Aga Khan University, Karachi, Pakistan

${ }^{2}$ Center of Excellence in Women and Child Health, Aga Khan University, Karachi, Pakistan ${ }^{3}$ Women \& Child Health Division, Aga Khan University, Karachi, Pakistan

${ }^{4}$ Implementation Research and Delivery Science Unit, Health Section, UNICEF, New York, USA

Correspondence to

Dr Shehla Zaidi;

shehlasaz@gmail.com

\section{ABSTRACT}

This paper compares the policy trajectories of Nutrition and Early Childhood Development (ECD) in Pakistan, identifying enablers that led to better multisector progress for Nutrition over ECD. Specifically, it deliberates on (1) multisector policy adoption in terms of instigation, construct and stakeholder coalitions; and (2) horizontal coordination in terms of capacity, incentives and structures. The analysis builds on existing work of the authors, supplementing this with further document review and expert insights. Nutrition and ECD initiatives in Pakistan, while overlapping agendas, differed in terms of buy-in and structural grounding. A favourable policy window for Nutrition was successfully managed through coordinated advocacy, programmatic support and investment in networks, while capture of policy opportunities was not seen in case of ECD. A vague construct for ECD confined its activities narrowly to the education sector while a Nutrition discourse specifying roles for other sectors resulted in a broader coalition and expanded activities. Both Nutrition and ECD faced powerful disincentives to coordination, but Nutrition overcame this through cofinancing of different sectors and creation of structural platform in supraplanning ministries. Both Nutrition and ECD share common capacity constraints for horizontal coordination, raising concerns for effective implementation. We conclude that multisector action for child well-being requires deliberative action and investment to unlock opportunities. The analysis from Pakistan highlights four governance areas for progressing multisector action: (1) opportune management of policy windows; (2) a clear and inclusive menu of actions for stakeholder coalitions; (3) availability of cofinancing and structural platforms for catalysing coordination; and (4) investment in horizontally placed human resource and integrated tracking systems.

\section{INTRODUCTION}

Child health and well-being interventions such as Nutrition and Early Childhood Development (ECD) are reliant on multiple sectors such as Health, Nutrition, Social Protection, Education, Food Security and WASH for effective execution. Globally, a favourable
Summary box

Multisector action is prominent in current global discourse for child's well-being, but there is a search for policy lessons on how an enabling environment for multisector action can be created.

- Nutrition, in comparison to Early Childhood Development (ECD), had better multisector buy-in, planning and structural platforms for multisector governance.

- Management of a favourable policy window, a crisp and inclusive action agenda, coordinated advocacy, and catalytic cofinancing created an enabling environment for multisector Nutrition but similar efforts were missing for $\mathrm{ECD}$.

- Both Nutrition and ECD are faced with weak coordination for multisector implementation.

- Implementation coordination requires dedicated investment to overcome inherent disincentives to multisector working.

- A different set of capabilities is required for implementation coordination involving horizontally placed human resource, and integrated resource tracking, planning and monitoring systems.

political environment now exists for undertaking multisector work for child well-being. The United Nations (UN) has also called on governments to 'strengthen governance and political commitment,' for Nutrition and $\mathrm{ECD}^{1}$ but search is under way on lessons for multisector policies and their effective programming. ${ }^{23}$

Under-Nutrition contributes to stunted child growth, impaired cognitive development and preventable mortality. The first 1000 days of life from pregnancy to a child's second birthday are critical, with important opportunities up to 5 years of age for reducing undernutrition. ${ }^{4}$ ECD has a broader mandate entailing social, cognitive and physical development from pregnancy, birth to a child's first 8 years of life. ${ }^{5}$ Both share underlying 


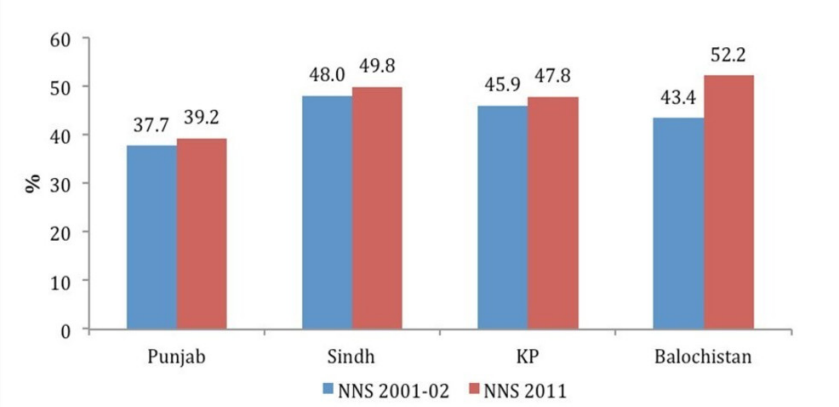

Figure 1 Stunting Trend Across Provinces: National Nutrition Survey (NNS).

determinants of access to healthcare, adequate dietary intake, water-sanitation-hygiene (WASH) and social protection, while ECD additionally involves cognitive stimulation provided by family support, preschool and primary education. Globally, a quarter of children under 5 years of experience are stunted for growth ${ }^{6}$ and $36.8 \%$ do not reach fundamental cognitive and socioemotional milestones. ${ }^{7}$

Nutrition has generated unprecedented policy dialogue over the last 6 years with a proliferation in global funding initiatives on Nutrition, ${ }^{8}$ and coordinated donor-government-civil society commitment through the global Scaling Up Nutrition (SUN) movement. ${ }^{9} 10$ On the other hand, ECD has been around much longer as a policy issue, with efforts speared by the World Bank in the 1990s but largely embedded in education programmes. ${ }^{11}$ Services globally remain fragmented, of variable quality and not implemented at scale. ${ }^{311}$ The Lancet Series on Maternal and Child Nutrition 2013 and the Lancet Early Childhood Development Series of $2016^{12}$ both emphasise interconnections required across sectors. However, despite much policy discourse on the need for multisector tackling of Nutrition and ECD, there is a search for lessons on how best to bring about multisector governance for child well-being initiatives. World Bank ${ }^{13}$ defines governance as the traditions and institutions by which authority in a country is exercised. Extension to collaborative governance is more challenging, less well understood and can benefit from further insights on political economy and public administration. ECD research has remained

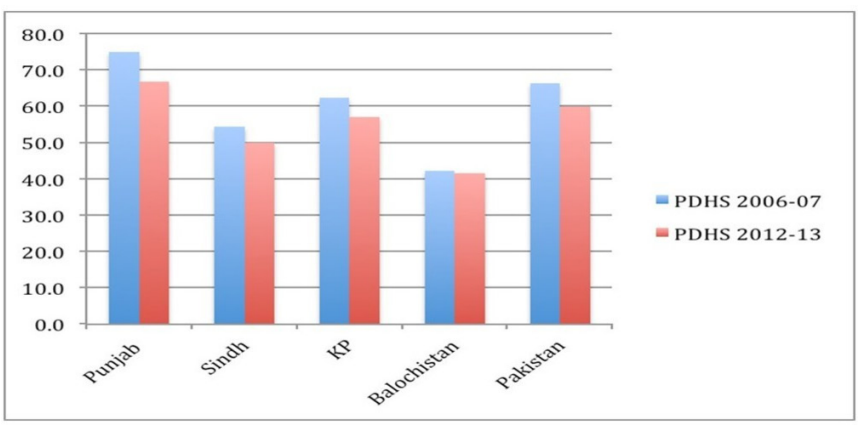

Figure 2 Net Primary School Enrollment Trend across Provinces: Pakistan Demographic \& Health Survey (PDHS). largely interventional while Nutrition has drawn more multisector governance focused evidence in recent years on explaining commitments, collaborations and capacities. $^{14-16}$

This paper tracks Nutrition and ECD initiatives in Pakistan highlighting key enablers and constraints for multisector working. Pakistan is a signatory to the 1990 UN Convention on Rights of the Child ${ }^{17}$ mainly implemented through initiatives in Health and Education sector. Multisector working for child well-being had however not been on the policy agenda until recently. In Pakistan, $45 \%$ of children under 5 are stunted $^{18}$ (figure 1) and net primary school enrolment is only $57 \%^{19}$ with little improvement over the last decade (figure 2). Although historically governed by a strong federating structure, in 2011 major devolution reforms changed the balance of authority with 21 subjects, including Health, Education and other social sector subjects, devolved to provinces for full policy, fiscal and operational responsibility. ${ }^{20}$ This has provided an opportunity for more manageable multisector coordination for child health at the subnational level and speedier translation into implementation. ${ }^{21} \mathrm{At}$ the same time, devolution also introduced challenges of varying priority for child well-being initiatives across different provinces.

We track the roll-out of Nutrition and ECD initiatives, comparing the policy trajectories in terms of multisector adoption and horizontal governance across sectors. Given that both Nutrition and ECD are under implementation in Pakistan, the analysis is confined to multisector adoption and early implementation, and does not measure implementation outcomes. Importance of defined leadership, multisector structural platforms and horizontal working capacity has been illustrated in existing literature. $^{1522}$ Our analysis builds on this and further incorporates issue construct and policy instigation, incentives and disincentives for multisector working. Hence, this paper tracks Nutrition and ECD trajectories in three areas: (1) how the construct and policy instigation of the issue lends itself to multisector working; (2) stakeholders' coalition in terms of breadth of stakeholders involved and defined leadership; and (3) horizontal coordination in terms of multisector platforms, incentives and capacities for horizontal working across different government ministries.

The analysis draws on the Nutrition Political Economy Analysis (PEA) ${ }^{23}$ Pakistan conducted over 2012-2013 and the landscape analysis on Preventing Undernutrition through Multisector Interventions (PUTMI). ${ }^{24} \mathrm{PEA}$ involved interaction with Education, Health, WASH, Agriculture, Food, Local Government, Women's Empowerment, Benazir Income Support Program (BISP), Social Protection, Planning and Development, Donor and UN agencies, experts and non-governmental organisations (NGO) through 84 informed consent interviews. Both PEA and PUTMI undertook desk review government strategies, plans and project proposals, budgetary outlay, notifications of multisector committees, donor nutrition investment strategies, project assessment reports, and so 
on. These two bodies of work drew in findings related to Nutrition as well as the interconnected area of ECD. These are supplemented with information from policy round tables and desk review for ECD and Nutrition over 2016 and 2017. A non-systematic scoping review was done of published online literature on Google Scholar, Medline, Popline and Google. Additionally, a website search of relevant government ministries, donor agencies and large NGOs was done for ECD and Nutrition initiatives.

\section{ISSUE INTERPRETATION AND INSTIGATION Early Childhood Development}

The instigation for ECD initially came in the late 1990s by the Aga Khan Development Network's investment in human resource development and evidence generation. Soon after exploratory discussions were held by aid agencies such as the ADB with the federal government but found a lukewarm response. ${ }^{25}$ Policy window in late 1990s was clearly favourable due to an emphasis by the military supported technocratic government on 'modern enlightenment' and human development. ${ }^{26}$ A National Commission of Human Development (NCHD) had been set up for housing special initiatives. ${ }^{27}$ However, the vague menu of action for $\mathrm{ECD}^{28}$ constrained its buying in within the NCHD and relevant ministries. Some governmental buy-in was instead realised for the Early Childhood Education (ECE) component of the larger ECD agenda. ECE was easily quantifiable as separate 'katchi' or preschool classes, supported by teacher training and parental involvement. The Dakar Framework for Action (2000) on ECE provided a further impetus for ECE. Hence found ready support from educationists within the technocratic government, as well as from NGOs and resource institutions. ${ }^{29}$ Similarly, within aid agencies working in Pakistan, ECD was confined to ECE and left in the ambit of the education teams. Education advisors within aid agencies shied away from the larger ECD agenda for fear it could be vulnerable to domination by their health counterparts.

ECE became incorporated in Pakistan's National Education Policy 1998-2010, recognising 'katchi' or preprimary as a formal class in primary schools. ${ }^{30}$ ECE was also incorporated in the National Plan of Action for Education 2001-2015 providing a plan of ECE provision to at least $50 \%$ of the population by $2015 .{ }^{31}$ This was followed in 2002 by the development of a National ECE curriculum $^{32}$ assisted by educationists and resource institutions (box 1).

ECE implementation was not at scale and involved NGO projects in focal districts supported by development agencies, Unicef or philanthropies but with weakly standardised activities $^{33}$ (box 1). Government implementation was planned for 2002-2005 as innovation in selected districts, but could not meaningfully take off because provinces showed little interest and failed to put up the cofinancing share to match federal Education
Box 1 ECE policy initistiatives Pakistan

National Education Policy (1998-2010)

Recognition of katchi/preprimary class as part of primary schooling

National Plan of Action (2001-2015)

Education for all long-term framework introduces ECD as one of its three areas of focus

\section{National ECE Curriculum (2002)}

Curriculum developed with participation of government, academic and resource agencies, updated 2007

\section{ECE Innovative Program (2001-2004)}

ECE classes in selected schools by provincial Education Reform Units funded by federal Education Ministry, with largest roll-out in Punjab

Resource Institutions and NGO Projects (2002-2009)

- Realising Confidence and Creativity by Aga Khan Foundation in Sindh, Baluchistan, KP, Northern Areas.

- Interactive Teaching by Children's Global Network in Punjab.

- Child Friendly Schools Programme by Children's Resources International in Islamabad.

- Early Learning Program by Sindh Education Foundation in seven districts of Sindh.

- ECCD Program by Plan International in selected Punjab districts.

- Training/learningmaterials by Idara-e-Taleem-0-Aagahi and Teacher Resource Centre in focal districts.

\section{Post devolution}

- Provincial Education Sector Strategies (2012-2018) incorporate ECD as part of primary education in all schools.

- Provincial funding provided for ECD classes, materials, training roll-out.

- ECD incorporated into multisector nutrition programming in Sindh and Punjab.

- Notification of National Task Force on ECD operated within National Nutrition Cell of Planning Commission.

ECD, Early Childhood Development; ECCD, Early Childhood Care and Development; ECE, Early Childhood Education; NGO, non-governmental organisation.

Ministry's allocation. ${ }^{34}$ After passage of provincial devolution in 2011, all four provinces have incorporated ECE in the provincial education sector strategies and earmarked budgets for ECE classrooms, training and teachers' salaries. ${ }^{35-38}$ However, schemes have been slow moving and ECE services are confined to some but not all public primary schools. Very recently, in 2017, ECD has been incorporated as part of national Nutrition programming efforts. An ECD Task Force has been notified by the Nutrition Section of the National Planning Commission and two of the larger provinces of Punjab and Sindh have incorporated ECD as part of their nutrition planning and budgets. ${ }^{39}$ Hence, the broader ECD agenda has become nested within the relatively smaller scoped agenda of Nutrition.

\section{Nutrition}

Nutrition historically had parallel activities in both the Health and Food Security sectors. Nutrition was raised as a health issue during the 1990s, focusing on 


\section{Box 2 Nutrition policy inititaives Pakistan}

Health initiatives: 1990-2000

- Baby Friendly Hospital Initiative by Paediatricians and Unicef.

- Edible oil incentives for pregnancy check-ups by World Food Program.

- Nutrition Wing in Ministry of Health.

- Vitamin A supplementation introduced in Polio Immunisation Campaigns.

- lodised Salt introduction by INGOs and MoH.

- Sprinkles and other micronutrient supplementation pilots- $\mathrm{MoH}$, INGOs, academia.

Food Security Initiatives: 1990s-2000s

- Wheat supply index monitoring.

- Wheat bags distribution by politicians in constituencies during disasters.

- Ration stores in urban centres and 'sasti roti' scheme in Lahore by local government.

- Charity kitchens by philanthropic outfits in Karachi and major cities.

- Tawana Pakistan girl child feeding project in schools by Ministry of Social Welfare.

\section{0 onwards}

- CMAM for flood affectees by United Nations (UN) agencies.

- Intersectoral Nutrition Strategies in all provinces.

- National Zero Hunger Program by Ministry of Food Security.

- Establishment of 'Food Regulatory Authority' in Punjab and Sindh.

- Nutrition projects under way in provincial Health funded by World Bank.

- Fortified edible oil and wheat flour project under way funded by Department For International Development, UK.

breast feeding promotion through baby friendly hospitals and supported by a network of paediatricians and the Unicef. ${ }^{40}$ By early 2000s, activities expanded to include salt iodisation, micronutrient implementation studies and Community Manangement of Acute Malnutrition $\mathrm{t}^{41}$ (box 2). Funding was small scaled, short term, largely uncoordinated and routed mainly through UN agencies and Intrenational non-government organizations (INGOs). ${ }^{21}$ In 2005, a Nutrition Wing was established in the Federal Ministry of Health $(\mathrm{MoH})$ to support micronutrient supplementation projects. On a parallel footing, economists and planners within the government have historically associated Nutrition with 'Hunger' with a primary focus on sufficient wheat production and market supply. ${ }^{42}$ In addition, from time to time there have been schemes popular with political representatives, for free or subsidised provision of food commodities, such as 'ration stores' for subsidised food supplies in cities, wheat flour bags distribution in disaster affected regions, 'Sasti roti' and 'sarkari kitchen' schemes to supply prepared food at low cost (box 2). ${ }^{23}$ Political support for hunger alleviation supported establishment of a National Food Security Task Force in 2008, followed by a National Ministry of Food Security in 2012 and a National Zero Hunger Plan in 2012. ${ }^{43}$

Instigation for a multisector construct to Nutrition came from a combination of global and local events during the period 2011-2012. At the global level, the SUN movement profiled Nutrition as a development rather than health agenda and an emergency for immediate action, managing to successfully mobilise donor aid support to countries such as Pakistan having a high burden of Under-Nutrition. At the same time, the publishing of the Lancet Series on Nutrition in 2008 and then 2013 provided cost-effective interventions, well advocated by development partners to policy circles in Pakistan. ${ }^{21}$ These coincided with local events in Pakistan. The widespread floods of 2010 and 2011 further served to highlight malnutrition in flood affectees to the general public-hence nutrition suddenly became visible. ${ }^{44}$ This was closely followed by the launch of the National Nutrition Survey (2011) providing dismal country and provincial statistics. These events were well advocated by development partners to the media, politicians and senior bureaucracy, using local experts and paediatricians as powerful advocates.

Consequently, Pakistan became a signatory to the SUN movement in 2012. ${ }^{45}$ Intersectoral Nutrition Strategies were developed over 2013 by all four provinces. At least three provincial governments are in process of programming and funding stunting reduction programmes in the sectors of Health, WASH, Food, Agriculture and Education. ${ }^{46}$ The momentum has already started in the Health sector with nutrition projects on ground across all four provinces, funded by the World Bank and partially cofinanced by provincial governments. ${ }^{47-50}$

\section{LEADERSHIP AND POLICY COALITIONS}

ECD and Nutrition, despite their overlapping agendas, have largely separate policy coalitions (figure 3 ).

ECD, brought forward as an education programming issue in Pakistan, had a small coalition confined to the education sector. Leadership for the ECD agenda kept on shifting from educationists to the federal government to more recently the provincial governments. Wellknown educationists from civil society and academic institutions formed linkages with educationists in the federal government towards ECE, although these linkages later weakened with movement out of educationists from the federal government. Development partners have provided piecemeal funding through local NGOs, semigovernment agencies and recently through international NGOs. ${ }^{33}$ Local researchers investigating ECD interventions found positive development changes through ECD interventions but no impact on physical growth. Neither ECE nor the larger ECD agenda was well advocated to political and bureaucratic leadership nor to district and local governments. ${ }^{28}$ Private schools in major cities of Pakistan provide ECE as part of an integrated curriculum but cater to the higher income groups and lack regulation by government. ${ }^{51}$ Despite an active media presence in Pakistan, ECE has not been effectively advocated to the media. 


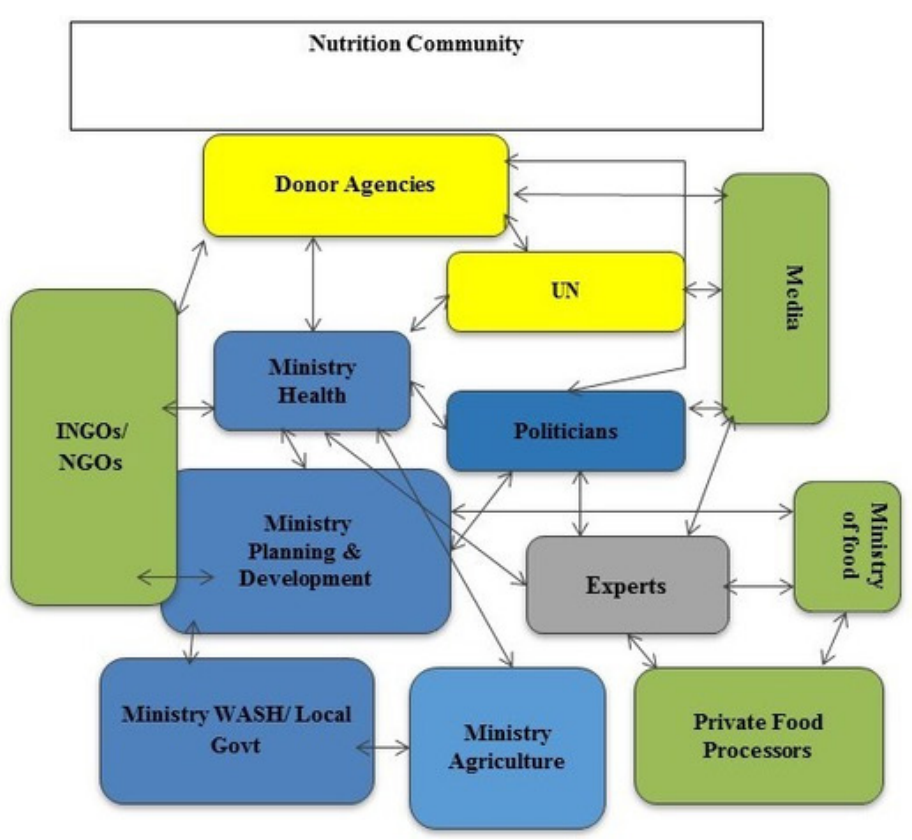

Figure 3 Stakeholder Communities for Nutrition and ECD

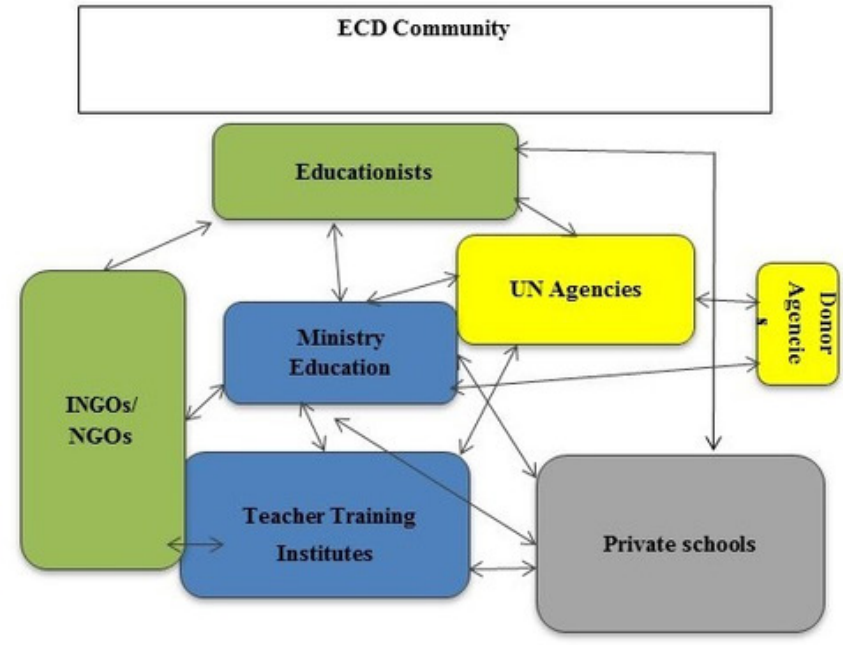

funding for SUN networks provided by UN agencies has catalysed interaction and exchange between business sector, NGOs, research entities and the government.

However, both Nutrition and ECD coalitions have failed to mobilise the Social Protection sector, despite Pakistan having a large national cash transfer programme targeting low-income women. Similarly, both Nutrition and ECD lack political champions to oversee implementation. Nutrition has had relative success with political championing in one province.

\section{HORIZONTAL COORDINATION}

Both Nutrition and ECD in Pakistan have weak coordination for multisector implementation.

\section{Structural platforms}

At the national level, the Planning Commission has a demarcated Nutrition section that serves to coordinate nutrition as a subject and serves as the secretariat for the SUN network. A multisector committee for ECD has been recently set up under the Nutrition section of the Planning Commission with a purpose to support the national nutrition targets. Provinces are the main hubs for planning, programming, funding and monitoring child's well-being initiatives in decentralised Pakistan. Nutrition planning, resourcing and oversight are being coordinated by the provincial P\&DDs in each province. ${ }^{24}$ This is significant as the $\mathrm{P} \& \mathrm{DD}$ is the overarching department for approval of projects across different ministries. ECD does not have a coordination platform in the provincial P\&DDs. District governments run by District Commissioner Offices are the natural implementation points to coordinate and monitor activities across the different sectors of Health, Education, WASH, Food, Agriculture, 
and so on. However, as yet there has been no move to create district-level platforms for either Nutrition or ECD. Local union council structures remain rudimentary and have not been administratively empowered for the delivery of social sector services beyond few services of WASH. ${ }^{62}$

\section{Incentives and disincentives to coordinate}

There are powerful structural disincentives for coordination presented by separate leadership, human resources and supply chains of different government departments. ${ }^{23}$ Nutrition, in contrast to ECD, has been able to get funded programmes in different provincial ministries of Health, WASH, Agriculture, Livestock, Population Welfare and Education in at least three provinces and an integrated stunting plan in place in two provinces. ECD has found recognition in education reform projects in the provinces but programming within Health, WASH and Social Protection sectors has not happened.

Donor financing and steering by nutrition champions within P\&DDs have been powerful incentives for proliferation of nutrition projects across sectors in provinces where progression has been seen. ${ }^{24}$ However, these ongoing multisector efforts are geared towards functional coordination through more integrated planning and there is reluctance of government ministries to share existing resources as well as competition for new funding. ${ }^{23}$ With separate government ministries managing nutrition projects, there is danger of discoordination during implementation in terms of geographies, timelines and vertical service delivery channels. At the same time, Health and Education provincial ministries continue to exert a powerful traction on Nutrition and ECD initiatives, respectively. Prior experience, comparatively skilled human resource, as well as being responsible for nutritional anthropometric measurement and primary school enrolment have provided Health and Education a visible domination over other relevant departments.

\section{Capacity for coordination}

Horizontal coordination capacity remains weak for both ECD and Nutrition. Although Nutrition is steered by the provincial P\&DDs, it is only in two provinces that a dedicated Nutrition cell supported by staff has been created and has successfully resulted in funded nutrition projects across multiple ministries. In the other two provinces, Nutrition is managed by the Health section of P\&DDs and programming has remained slow due to lack of legitimacy of the Health section to effectively steer other sections as well as dedicated staff time to oversee Nutrition activities. All P\&DDs lack a system for integrated resource tracking across sectors and have become particularly challenging with growth in the number of international donors, UN agencies and INGOs providing support. ${ }^{24}$ Similarly, lack of target setting for each of the relevant ministries and absence of an integrated performance tracking systems blunts effective overseeing of Nutrition and ECD initiatives. There are also unmet capacity gaps within the vertical ministries. Ministries other than Health and Education lack area specialists for ECD and Nutrition constraining what to programme and monitor. Furthermore, all relevant ministries including Health and Education lack regulatory capacity to mainstream Nutrition and ECD across public and private providers.

\section{CONCLUSION}

The overlapping agendas of Nutrition and ECD initiatives in Pakistan differed in terms of multisector buy-in and structural grounding; however, both face common capacity constraints for multisector implementation. We come across four areas to be of relevance for creating an enabling environment, as discussed below.

First, experience from Pakistan shows that coordinated management of policy events is required to get multisector political commitment, taking advantage of windows of opportunity. In the case of Nutrition in Pakistan, a donor wave of funding, well-planned evidencebased advocacy and local floods helped in opening a window of opportunity for multisector commitment. ECD, in contrast, grappled to find political commitment as a multisector agenda, remaining confined to the Education sector and small-scale delivery. In the case of ECD, insufficient donor mobilisation and less tangible visibility compared with Nutrition blunted the possibility of larger political buy-in.

Second, we found that issue construction (particularly in terms of incentives for other sectors) was key to shaping ownership. In Pakistan, the vague construct of ECD and lack of a crisp menu of actions beyond Education resulted in a narrow coalition. Low policymaker unawareness for ECD is a commonly faced issue in South Asia and has proved detrimental for mobilising funding. ${ }^{63}$ Nutrition was successful in getting a coalition representing different sectors in Pakistan, helped along by deliberative investment in multisector networking. Lack of clarity on role of sectors can result in slow policy translation.

The need for an identified champion for multisector agendas has been advocated by international experts. ${ }^{64}$ In Pakistan, ECD lacked a champion due to being poorly understood while Nutrition, despite garnering political commitment, failed to come up with a defined leadership which has slowed implementation. Experience from Uganda similarly shows widening coalitions but lack of national champions such as celebrities and parliamentarians with whom the public can identify. ${ }^{65}$

Third, incentives and disincentives for coordination need to be recognised and addressed. In Pakistan, Health and Education sectors continued to exert powerful influence over Under-Nutrition and ECD undermining participation of other sectors. In the case of Nutrition, this was overcome through a structural platform in national and subnational planning ministries and donor cofinancing of programmatic activities in nutrition sensitive sectors. Structural platforms are not commonly found for ECD even in countries of high commitment such as 
Columbia ${ }^{66}$ but are increasingly seen for Nutrition as in $\mathrm{Peru}^{67}$ and certain African countries. There is comparatively less known on what makes them work.

Lastly, horizontal coordination cannot happen effortlessly and has its distinctive capacity needs. These included designated staff for coordination, systems for integrated planning, resource tracking and performance tracking across sectors, district platforms, and placement of subject specialists within key supporting ministries to help them programme for Nutrition and ECD.

In conclusion, multisector action for child well-being requires deliberative action and investment to unlock opportunities. Our findings from Pakistan highlight three governance areas that helped progress Nutrition as a multisector agenda and can be applied to ECD: (1) opportune management of policy windows; (2) a clear and inclusive menu of actions for stakeholder coalitions; and (3) availability of cofinancing and structural platforms for catalysing coordination. A common gap across both Nutrition and ECD is weak coordination capacity and requires investment in horizontally placed human resource, district coordination platforms and integrated systems for planning, resourcing and performance tracking.

Contributors SAZ and KR conceptualised the framing of the paper. SAZ and ZB undertook the analysis assisted by SSH. SAZ wrote the paper, while review and inputs were made by ZB, SSH and KR. SAZ and ZB respectively led the PEA and PUTMI works, SSH assisted with additional documentary review and stakeholder discussions, SAZ and KR conceptualised the paper with review by ZB.

Funding The authors have not declared a specific grant for this research from any funding agency in the public, commercial or not-for-profit sectors.

Competing interests None declared.

Patient consent Not required.

Provenance and peer review Not commissioned; externally peer reviewed.

Data sharing statement № additional data are available.

Open access This is an open access article distributed in accordance with the Creative Commons Attribution Non Commercial (CC BY-NC 4.0) license, which permits others to distribute, remix, adapt, build upon this work non-commercially, and license their derivative works on different terms, provided the original work is properly cited and the use is non-commercial. See: http://creativecommons.org/ licenses/by-nc/4.0/

(c) Article author(s) (or their employer(s) unless otherwise stated in the text of the article) 2018. All rights reserved. No commercial use is permitted unless otherwise expressly granted.

\section{REFERENCES}

1. WHO. Global nutrition policy review: what does it take to scale up nutrition action? 2013

2. Gillespie S, Haddad L, Mannar V, et al. The politics of reducing malnutrition: building commitment and accelerating progress. Lancet 2013;382:552-69.

3. Daelmans B, Darmstadt GL, Lombardi J, et al. Early childhood development: the foundation of sustainable development. The Lancet 2017;389:9-11.

4. Grantham-McGregor S, Cheung YB, Cueto S, et al. Developmental potential in the first 5 years for children in developing countries. Lancet 2007;369:60-70.

5. Black MM, Walker SP, Fernald LCH, et al. Early childhood development coming of age: science through the life course. Lancet 2017;389:77-90.
6. Black RE, Victora CG, Walker SP, et al. Maternal and child undernutrition and overweight in low-income and middle-income countries. Lancet 2013;382:427-51.

7. McCoy DC, Peet ED, Ezzati M, et al. Early childhood developmental status in low- and middle-income countries: national, regional, and global prevalence estimates using predictive modeling. PLoS Med 2016;13:e1002034.

8. IFPRI. Global nutrition report: actions and accountability to accelerate the world's progress on nutrition. Washington, DC: International Food Policy Research Institute, 2016.

9. SUN. Scaling up nutrition movement progress report: SUN Movement Secretariat, 2011.

10. World Health Organization. Report of the commission on ending childhood obesity: implementation plan. 2017 http://apps.who.int/ iris/bitstream/10665/259349/1/WHO-NMH-PND-ECHO-17.1-eng.pdf

11. Young ME, Richardson LM. Early child development; from measurement to action. The World Bank Washington, DC. 2007 https://openknowledge.worldbank.org/bitstream/handle/ 10986/6837/409250PAPER0Ea101OFFICIALOUSEOONLY1.pdf; sequence $=1$

12. Menu ENN, Exchange F. Advancing early childhood development: from science to Scale, 2016.

67. World Bank. Governance and Development. Washington DC: The World Bank, 1992. http://documents.worldbank.org/curated/en/ 604951468739447676/Governance-and-development

14. Lamstein S, Pomeroy-Stevens A, Webb P, et al. Optimizing the multisectoral nutrition policy cycle: a systems perspective. Food Nutr Bull 2016;37(4 suppl):S107-S14.

15. Acosta MA, Fanzo J. Effective governance and policies to improve nutrition outcomes: a cross comparison of nine country cases. Ann Nutr Metab 2013;63:854.

16. Hoey L, Pelletier DL. Bolivia's multisectoral Zero Malnutrition Program: insights on commitment, collaboration, and capacities. Food Nutr Bull 2011;32(2 Suppl):S70-S81.

17. UN. Convention on the rights of the child. Washington DC, USA: United Nations, 2008.

18. GoP. National nutrition survey. Planning and development division, government of Pakistan, 2011.

19. GoP. Pakistan social and living standards measurement survey Pakistan Bureau of Statistics, Islamabad 2016:2014-5.

20. GoP. 18th amendment report national assembly of Pakistan, 2010.

21. Zaidi S, Mohmand SK, Hayat N, et al. Nutrition policy in the post-devolution context in Pakistan: an analysis of provincial opportunities and barriers*. IDS Bull 2013;44:86-93.

22. Pelletier D, Gervais S, Hafeez-Ur-Rehman H, et al. Boundaryspanning actors in complex adaptive governance systems: the case of multisectoral nutrition. Int $J$ Health Plann Manage 2018;33:e293-e319.

23. Zaidi S, Bhutta ZA, Mohmand SK, et al. The political economy of undernutrition national report: Pakistan, 2013.

24. Heart. Preventing undernutrition through multi-sectoral initiatives in pakistan; a landscape analysis, Washington, DC 20001 USA 2015 http://www.heart-resources.org/wp-content/uploads/2015/08/ PUTMI-Landscape-Report-FINAL 31-07-2015.pd

25. Ahmad M. Early childhood education in Pakistan: an international slogan waiting for national attention. Contemporary Issues in Early Childhood 2011;12:86-93.

26. TALBOT IAN. General Pervez Musharraf: Saviour or destroyer of Pakistan's democracy? Contemp South Asia 2002;11:311-28.

27. National Commission for Human Development. Let's join hands to promote quality education in Pakistan. 2013 http://www.nchd.org. $\mathrm{pk} / \mathrm{ws} /$ documents/2013.pdf

28. Rich-Orloff W, Khan J, Juma A. Early childhood education in Pakistan: evaluation report of USAID's supported programs, devtech systems, Inc. 2007 https://usaid.gov/pdf docs/Pdack938.pdf

29. Hunzai ZN. Early years education in Pakistan: trends, issues and strategies. Int J Early Years Educ 2007;15:297-309.

30. Ministry of Education, Pakistan. National education policy (19982010). http://unpan1.un.org/intradoc/groups/public/documents/ APCITY/UNPAN014613.pdf

31. Ministry of Education. National report on the development of education: Pakistan. Islamabad, Pakistan. 2008 http://www.ibe. unesco.org/National Reports/ICE 2008/pakistan_NR08.pdf

32. Ministry of Education. National curriculum: early childhood education. Ministry of Education (Curriculum Wing) Islamabad, Pakistan. 2002 http://aserpakistan.org/document/learning resources/2014/Early_Childhood_Education/ECE.pdf

33. Khan F, Ali AG, Kabani A. Early childhood development initiatives in Pakistan: a mapping study. Sindh Education Foundation. 2010 http://www.sef.org.pk/images/publications/ECD-mappingstudy/ecdmapping-study.pdf 
34. Ministry of Education. ECE policy review: policies, profile and programs of Early Childhood Education (ECE) in Pakistan. Federal Ministry of Education and Children's Resources, International. 2008 http://www.unescobkk.org/fileadmin/user upload/appeal/ECCE/ reports_and_publications/Final_Policy_Review_Report-_ECCE_ pakistan.pdf

35. Government of Sindh. Sindh education sector plan: $2013-2016$ 2013 http://www.aserpakistan.org/document/learning_resources/ 2014/Sector_Plans/SindhSectorPlan2013-2016.pdf

36. Government of Punjab. Punjab School Education Sector Plan: 20132017. $2013 \mathrm{http}: / /$ aserpakistan.org/document/learning_resources/ 2014/Sector_Plans/PunjabSectorPlan2013-2017.pdf

37. Government of Khyber Pukhtunkhwa. Education Sector Plan: 20102015. Elementary and Secondary Education Department 2012. http://itacec.org/document/sector_plans/ECEinPakistanProvincialS ectorPlans.pdf

38. Government of Baluchistan. Balochistan education sector plan: 2013-2018. Policy planning and implementation unit 2013. http:// emis.gob.pk/Uploads/BalochistanEducationSectorPlan.pdf

39. Government of Sindh. Sindh accelerated action plan for reduction of stunting and malnutrition: sehatmand sindh: Planning \& Development (Nutrition section), Government of Sindh, 2016.

40. Khan M, Akram DS. Effects of baby-friendly hospital initiative on breast-feeding practices in sindh. J Pak Med Assoc 2013;63:34.

41. Technical Resource Facility. Nutrition mapping and proposing options for scale up in Pakistan 2012. http://www.trfpakistan.org/ Portals/18/TRFreports/MNCH/Nutritionmappingandoptionsforsca leup2012.pdf?ver=2017-03-22-181031-467

42. World Food Programme. Pakistan food security bulletin. vulnerability analysis and mapping. United Nations. 2015;3 http://vam.wfp.org. pk/Publication/PFSB August_2015.pdf

43. National Actions for Zero Hunger. Office of the special representative of secretary general - food security \& nutrition. 2015 http://www.un. org/en/zerohunger/pdfs/ZeroHungercountryactionsDec_2015.pdf

44. Hossain SMM, Talat M, Boyd E, et al. Evaluation of Nutrition Surveys in Flood-affected Areas of Pakistan: Seeing the Unseen!. IDS Bull 2013:44:10-20.

45. Scaling Up Nutrition Movement. Declaration of commitments on the launch of scaling up nutrition movement in pakistan. pearl continental Hotel, Bhurban, Pakistan. 2013 http://scalingupnutrition. org/wp-content/uploads/2014/02/Pakistan-SUN-LaunchDeclaration.pdf

46. Department for International Development. Preventing under nutrition through multi-sectoral initiatives in Pakistan: a landscape

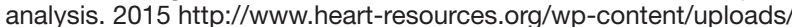
2015/08/PUTMI-Landscape-Report-FINAL_31-07-2015.pdf

47. Government of Baluchistan. PC-1: nutrition programme for baluchistan. Nutrition Programme Baluchistan: Health Department, Government of Baluchistan, 2014.

48. Government of Khyber Pakhtunkhwa. PC-1: nutrition programme for KPK: Nutrition Programme KPK, Health Department, Government of KPK, 2014.

49. Government of Punjab. PC-1: nutrition programme for Punjab: Nutrition Programme Punjab, Health Department, Government of Punjab, 2014.

50. Government of Sindh. $P C$-1: nutrition programme for Sindh: Nutrition Programme Sindh, Health Department, Government of Sindh, 2014.
51. Ministry of Education. National report on the development of education: pakistan ministry of education Islamabad, Pakistan. 2008 http://www.ibe.unesco.org/National_Reports/ICE_2008/pakistan_ NR08.pdf

52. Business Recorder. Stunting: a national emergency. 2016 http:// epaper.brecorder.com/2016/10/10/2-page/801658-news.html

53. DFID's Contribution to Improving Nutrition. Independent commission for aid impact 2014 (36). https://icai.independent.gov.uk/wp-content/ uploads/ICAI-REPORT-DFIDs-Contribution-to-Improving-Nutrition. pdf

54. The World Bank. Pakistan development update: making growth matter The World Bank 2016. http://documents.worldbank.org/ curated/en/935241478612633044/pdf/109961-WP-PUBLICdisclosed-11-9-16-5-pm-Pakistan-Development-Update-Fall-2016with-compressed-pics.pdf

55. European Union. Action document for "Programme for Improved Nutrition in Sindh (PINS)". 2016(2016/038-937). https://ec.europa. eu/europeaid/sites/devco/files/aap-financing-pakistan-annex4-c 2016_8487_en.pdf

56. United Nations Children's Fund. Pakistan annual report, Pakistan 2015 https://www.unicef.org/pakistan/FINAL_UNICEF_Annual_ Report_2015_.pdf

57. World Food Programme. Fighting hunger worldwide: the world food programme's year in review. 2010 http://documents.wfp.org/ stellent/groups/public/documents/communications/wfp236112. pdf

58. Pakistan Muslim League (N). National agenda for real change, manefesto. 2013 http://pmo.gov.pk/documents/manifesto.pdf

59. Citizens Wire. Pakistan people's party parliamentarians manifesto. 2013 http://www.citizenswire.com/wp-content/uploads/2013/03/ PPPP Manifesto 14 3 13.pdf

60. Pakistan Tehreek-e-Insaf Manifesto. PTI maifesto election 2013. http://www.insaf.pk/about-us/know-pti/manifesto.

61. Muttahida Qaumi Movement manifesto. Empowering people MQM manifesto 2013. http://www.mqm.org/Assets/MQM-Manifesto-2013Eng.pdf

62. Social Science and Policy Bulletin. Department of economics, lahore university of management sciences. 2009 https://lums. edu.pk/sites/default/files/research-publication/sspb-vol-1-no1summer2009.pdf

63. Das D, Mohamed H, Saeed MT, et al. World Bank/UNICEF. Strategic Choices for Education Reforms. Early Childhood Development in Five South Asian Countries. http://siteresources.worldbank.org/ EDUCATIONLP/Resources/460908-1209498676534/49507691217974426107/SouthAsiaECDPaper1.pd

64. Haddad L, Acosta AM, Fanzo J. Accelerating reductions in undernutrition: what can nutrition governance tell us. Institute of Development Studies: University of Sussex Brighton, 2012.

65. Pomeroy-Stevens A, D'Agostino A, Adero N, et al. Prioritizing and funding the Uganda nutrition action plan. Food Nutr Bull 2016;37(4 suppl):S124-S141.

66. Colombia. Early childhood development. SABER country report 2013. http://wbgfiles.worldbank.org/documents/hdn/ed/saber/ supporting_doc/CountryReports/ECD/SABER_ECD_Colombia_CR Final_2013.pdf

67. Acosta AM. Analysing success in the fight against malnutrition in Peru. IDS Working Papers 2011;2011:2-49. 